\title{
Effect of Betel Leaf and Lemon Juice Extracts on Staphylococcus aureus in vitro
}

\author{
A. Kumari ${ }^{1}$ and S. Bhattacharya ${ }^{2 *}$ \\ ${ }^{1}$ Department of Microbiology, B. Lal Institute of Biotechnology, Jaipur, India \\ ${ }^{2}$ Department of Microbiology, AIIMS Patna, India \\ *Corresponding author
}

\section{A B S T R A C T}

\section{Keywords \\ Staphylococus aureus, Biofilm, Virulence. \\ Article Info \\ Accepted: \\ 28 October 2017 \\ Available Online: \\ 10 December 2017}

Staphylococcus aureus is a smart, often drug-refractory pathogen. This necessitates use of alternate compounds as possible therapeutic options. So we tested the efficacy of extracts of betel leaf and lemon on growth, biofilm formation and virulence factors of this pathogen. Both the extracts showed marked inhibition of the pathogen at high concentrations. The extracts were also non-toxic to the host RBC and WBCs. Hence they can be considered as putative therapeutic options against this pathogen.

\section{Introduction}

Staphylococcus aureus is an extremely virulent bacterium causing multiple infections in man, like superficial and deep seated infections and also toxin mediated infections (1). This bacterium is usually resistant to multiple antibiotics, like Methicillin and others, which often makes treatment very difficult (2). Treatment can be intiated with Vancomycin in MRSA, but the latter drug is itself very toxic (3). Moreover Vancomycin indeterminate $S$. aureus (VISA) and Vancomycin resistant S. aureus (VRSA) are also emerging (2). Hence scientists are now focussing on newer and natural alternative compounds to inhibit or kill S. aureus from clinical samples. Sometimes even of bacteria are not killed due to refractoriness to some compounds or antibiotics, their virulence can be mitigated by some natural components.

The effect of ethanolic extract of paan leaf has already been demonstrated on some clinical strains of Proteus spp., P. aeruginosa and $S$. aureus (4). Lemon peel and juice have also shown some promising action against mostly Gram negative bacteria causing various infections (5).

Keeping these things in mind, our study was planned to test the efficacy of extracts of betel leaf (paan) and lemon juice of this pathogen and its virulence traits, and also to see the synergistic effect of some antibiotics with these extracts, on $S$. aureus isolates. 


\section{Materials and Methods}

This was a lab based observational study carried out in OPD and department for a period of 5 months from June 2017 to November 2017. Ethical clearance was obtained from the institute before starting the study. Paan leaves and lemon (Citrus limon) were sourced from local vendors, each time from a different vendor. Sweet variant of paan leaf was used. Common lemon was used. Isolates of $S$. aureus were selected randomly from laboratory isolates which were identified by Gram staining, anaerobic mannitol fermentation reaction and positive slide and tube coagulase tests. Paan and lemon juice extracts were prepared by weighing 1 gram paan leaf (dried) and lemon juice in $100 \mathrm{ml}$ Peptone water $(\mathrm{pH} 7)$. Other concentrations like $2 \%$ and $4 \%(\mathrm{w} / \mathrm{v})$ were also tested. They were autoclaved at $10 \mathrm{lbs} / \mathrm{in}^{2}$ pressure. Isolates were emulsified in (a) $2 \mathrm{ml}$ peptone water, and (b) $2 \mathrm{ml}$ of the extracts, and in both a turbidity of 0.5 MacFarland standard was made. After overnight incubation at $37{ }^{\circ} \mathrm{C}, 1$ loopful from each sets of suspension were subcultured on Mueller Hinton agar and Egg yolk agar. Both media were again incubated similarly at the same temperature. Lecithinase, lipase and protease were denoted on Egg yolk agar by the presence of haziness around colonies, clearing around colonies and pearly sheen on surface of colonies, respectively. Mueller Hinton agar was used to see and compare reduction of colonies due to effect of extract. Time kill analysis was also performed wherein liquid broths were subcultured after every 30 minutes, 1 hour, 2 hours and 4 hours on solid media to see the time when growth inhibition starts. Similarly Egg yolk agar was used to see the alterations of the virulence traits due to effect of extract. Then the growths in peptone water and extracts were decanted, washed thrice with sterile physiological saline and washed for 1 minute with $1 \%$ aqueous safranine. They were again washed with sterile saline, inverted and dried, and observed visually for biofilm formation (test tube method). Antibiotic susceptibility of the isolates were done by Kirby-Bauer disk diffusion method, using common antibiotics like Cefoxitin $(30 \mu \mathrm{g})$, Azithromycin $(15 \mu \mathrm{g})$, Clindamycin $(2 \mu \mathrm{g})$, Cotrimoxazole $(25 \mu \mathrm{g})$ and Amikacin $(30 \mu \mathrm{g})$ (6). Another set of antibiotic susceptibility was carried out by putting up disks of antibiotics on MHA, and adding $20 \mu \mathrm{l}$ from each concentration of extract over the paper disks of antibiotics and then incubation. All results were calculated and compared. Then the toxicity of the extracts was also tested by mixing 1 drop of buffy coat from plasma samples received in lab and as left-over from other tests, and observing the mount microscopically for 30 minutes. All tests were done thrice.

\section{Results and Discussion}

Both paan and lemon showed inhibitory action against $S$. aureus, more with lemon juice. Inhibition was more marked with $4 \%$ extracts as compared to other concentrations. $\mathrm{pH}$ of lemon juice was 5.5 while paan extract was about 6.5. Lemon juice contained some proteins and essential amino acids like Leucine. The extracts were non-toxic to human WBCs and RBCs. Chemical analysis of the extracts showed no ketones in extracts, protein concentration of $6 \mu \mathrm{g} / \mathrm{ml}$ in both extracts at all concentrations, sugar level of $12.8 \mu \mathrm{g} / \mathrm{ml}$ in $2 \%$ Paan and $2 \%$ lemon extracts, and $0.8 \mu \mathrm{g} / \mathrm{ml}$ and $1.2 \mu \mathrm{g} / \mathrm{ml}$ in $2 \%$ and $4 \%$ lemon extracts, respectively.

The lemon extracts showed qualitatively large amounts of detectable Leucine by commercial dip=stick methods. Tables 1-5 further illustrate the effects. Zone size increase by synergistic effect was only shown by $4 \%$ paan extract and has been shown below. 
Table.1 Effect of $1 \%$ paan and $1 \%$ lemon

\begin{tabular}{|c|l|c|c|c|c|c|}
\hline & \multicolumn{2}{|l|}{$\begin{array}{l}\text { Total } \\
\text { number of } \\
\text { exp. }\end{array}$} & $\begin{array}{l}\text { Normal Peptone } \\
\text { water }\end{array}$ & \multicolumn{2}{|l|}{$\begin{array}{l}\text { 1\% PAAN Extract with } \\
\text { peptone water }\end{array}$} & \multicolumn{2}{l|}{$\begin{array}{l}\text { 1\% Lemon Extract with } \\
\text { peptone water }\end{array}$} \\
\hline Bio film & 55 & 55 & 42 & 13 & 42 & 13 \\
\hline Growth & 55 & 55 & 55 & 00 & 55 & 00 \\
\hline Lipase & 55 & 55 & 52 & 03 & 55 & 00 \\
\hline Protease & 55 & 55 & 04 & 51 & 04 & 51 \\
\hline Lecithinase & 55 & 55 & 00 & 55 & 02 & 53 \\
\hline
\end{tabular}

Positive: Organisms growth have seen in different \% of PAAN and Lemon extract

Negative: Organisms growth have inhibited in different $\%$ of PAAN and Lemon extract

Table.2 Effect of $2 \%$ paan and $2 \%$ lemon

\begin{tabular}{|c|c|c|c|c|c|c|}
\hline & \multirow[t]{2}{*}{$\begin{array}{l}\text { Total number } \\
\text { of exp. }\end{array}$} & \multirow[t]{2}{*}{$\begin{array}{c}\text { Normal Peptone } \\
\text { water }\end{array}$} & \multicolumn{2}{|c|}{$\frac{\text { 2\% PAAN Extract with }}{\text { peptone water }}$} & \multicolumn{2}{|c|}{$\frac{\text { 2\% Lemon Extract with }}{\text { peptone water }}$} \\
\hline & & & Positive & Negative & Positive & Negative \\
\hline Bio film & 30 & 30 & 25 & 05 & 25 & 05 \\
\hline Growth & 30 & 30 & 22 & 08 & 24 & 06 \\
\hline Lipase & 30 & 30 & 20 & 10 & 20 & 10 \\
\hline Protease & 30 & 30 & 04 & 26 & 04 & 26 \\
\hline Lecithinase & 30 & 30 & 02 & 28 & 02 & 28 \\
\hline
\end{tabular}

Positive: Organisms growth have seen in different \% of PAAN and Lemon extract

Negative: Organisms growth have inhibited in different $\%$ of PAAN and Lemon extract

Table.3 Effect of $4 \%$ paan and $4 \%$ lemon

\begin{tabular}{|c|c|c|c|c|c|c|}
\hline & \multirow[t]{2}{*}{$\begin{array}{l}\text { Total number } \\
\text { of exp. }\end{array}$} & \multirow[t]{2}{*}{$\begin{array}{c}\text { Normal Peptone } \\
\text { water }\end{array}$} & \multicolumn{2}{|c|}{$\frac{\text { 4\% PAAN Extract with }}{\text { peptone water }}$} & \multicolumn{2}{|c|}{$\frac{4 \% \text { Lemon Extract with }}{\text { peptone water }}$} \\
\hline & & & Positive & Negative & Positive & Negative \\
\hline Bio film & 25 & 25 & 03 & 22 & 20 & 05 \\
\hline Growth & 25 & 25 & 03 & 22 & 20 & 05 \\
\hline Lipase & 25 & 25 & 03 & 22 & 20 & 05 \\
\hline Protease & 25 & 25 & 00 & 25 & 00 & 25 \\
\hline Lecithinase & 25 & 25 & 00 & 25 & 00 & 25 \\
\hline
\end{tabular}

Positive: Organisms growth have seen in different \% of PAAN and Lemon extract

Negative: Organisms growth have inhibited in different $\%$ of PAAN and Lemon extract

Table.4 Time-kill assay for inhibitory effect of lemon

\begin{tabular}{|c|c|c|c|c|c|c|}
\hline & $\begin{array}{l}\text { Total number } \\
\text { of experiment }\end{array}$ & $\begin{array}{l}\text { After } 30 \\
\text { minutes }\end{array}$ & After 1 hours & $\begin{array}{c}\text { After } 2 \\
\text { hours }\end{array}$ & After 4 hours & After 24 hours \\
\hline $\begin{array}{l}\text { L2(2\% } \\
\text { lemon) }\end{array}$ & 10 & $10(+)$ & $10(+)$ & $10(+)$ & $10(+)$ & $03(-) ; \quad 07(+)$ \\
\hline $\begin{array}{l}\text { L4 (4\% } \\
\text { lemon) }\end{array}$ & 10 & $10(+)$ & $10(+)$ & $10(+)$ & $0(+)$ & $08(-) ; \quad 02(+)$ \\
\hline
\end{tabular}

+: positive growth

-: negative growth 
Table.5 Sensitivity zone size

\begin{tabular}{|l|l|l|l|l|l|l|l|}
\hline AB disc & NET & AZM & CX & COT & CD & FR & LEVO \\
\hline On MHA media & $26 \mathrm{~mm}$ & Resistant & $6 \mathrm{~mm}$ & $22 \mathrm{~mm}$ & $15 \mathrm{~mm}$ & Resistant & $22 \mathrm{~mm}$ \\
\hline $\begin{array}{l}\text { On MHA AB } \\
\text { disc with P4 } \\
\text { 20 } \boldsymbol{\mu} \text { (4\% paan) }\end{array}$ & $32 \mathrm{~mm}$ & $6 \mathrm{~mm}$ & $15 \mathrm{~mm}$ & $22 \mathrm{~m}$ & $28 \mathrm{~mm}$ & $28 \mathrm{~mm}$ & $28 \mathrm{~mm}$ \\
\hline
\end{tabular}

MSSA and MRSA pose serious health threats
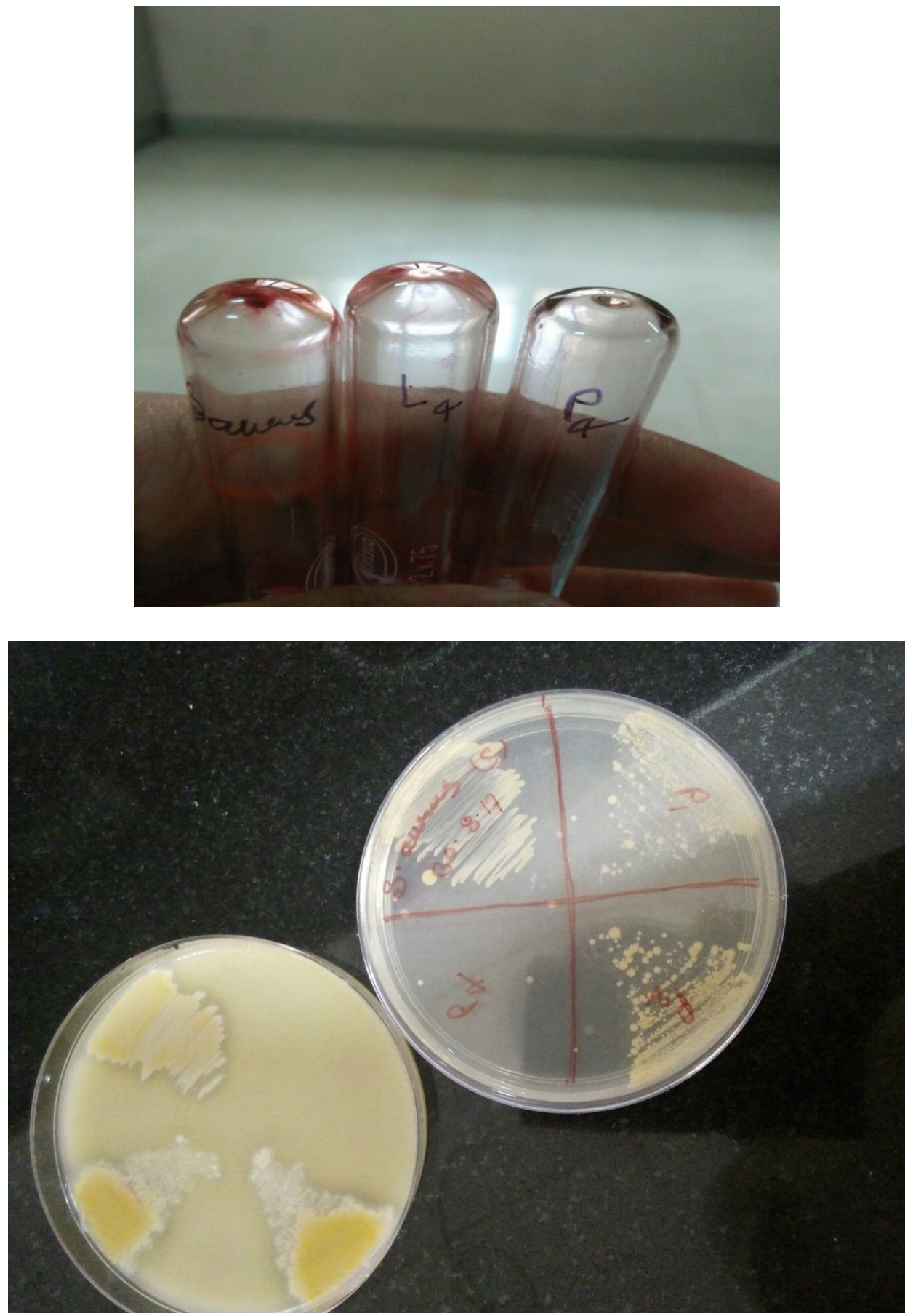
Both MSSA and MRSA pose serious health threats. They are notorious for causing deadly infections like pneumonia, osteomyelitis and skin infections, both in community and outpatient setting (7). Being notoriously resistant to multiple antibiotics, there is acute and urgent need of natural and alternative compounds to treat infection by $S$. aureus.

Betel leaf is a common ingredient of Indian dishes and also very commonly used as a mouth freshener (4). It is widely available and cultivated in Malaysia, India and Thailand among other South Asian countries. These aspects have not been seen or studied earlier and are quite interesting. Since there was inhibition of virulence factors, this can used as anti-virulence therapy in this pathogen causing infections.

Also synergistic effects with antibiotics were observed, which means that they can be used in conjunction with antibiotics also and there was no inhibition of effect of antibiotics. The putative inhibitory molecule in lemon extract on $S$. aureus isolates can be Leucine, since invitro it has shown to be antibacterial, as reported in several studies (8)

More studies are awaited in this regard. Mostly effects started after 4 hours of incubation. Since autoclaved extracts were used, it means it can be used in febrile states also. Extracts were also non-toxic and hence presumably safe for human use.

Paan and lemon juice can be used to treat $S$. aureus infection at least in-vitro, and further in-vivo studies can confirm these findings.

\section{References}

1. Foster T. Chapter 12. Staphylococcus. Medical Microbiology. 4th edition. Baron S, editor. Galveston (TX): University of Texas Medical Branch at Galveston; 1996.

2. Chambers HF, DeLeo FR. Waves of Resistance: Staphylococcus aureus in the antibiotic era. Nat Rev Microbiol 2009 September; 7(9): 629-641.

3. Rocha JLL, Kondo W, Baptista MIDK, da Cinha CA, Martins LTF. Uncommon vancomycin-induced side effects. http://www.scielo.br/pdf/bjid/v6n4/v6n4 a07.pdf

4. Datta A, Ghoshdastidar S, Antimicrobial property of piper betel leaf against clinical isolates of bacteria. International J Pharma Sci Res ;.2(3), 2011,104-109

5. Hindi NKK, Chabuck ZAG. Antimicrobial activity of different aqueous lemon extracts. Journal of Applied Pharmaceutical Science 2013; 3 (6):74-78.

6. Bauer AW, Kirby WMM, Sherris JC, Turck M Antibiotic susceptibility testing by a standardized single disc method. Am J Clin Pathol 1966: 45: 493

7. Boucher H, Miller LG, Razonable RR. Serious infections caused by methicillin-resistant Staphylococcus aureus. Clinical Infect Dis 2010:51 (Suppl 2): S183-S197.

8. Fox SW, Fling M, Bollenback GN. Inhibition of bacterial growth by $\mathrm{D}$ Leucine. J. Biol. Chem. 1944, 155:465468.

\section{How to cite this article:}

Kumari, A. and Bhattacharya, S. 2017. Effect of Betel Leaf and Lemon Juice Extracts on Staphylococcus aureus in vitro. Int.J.Curr.Microbiol.App.Sci. 6(12): 4329-4333. doi: https://doi.org/10.20546/ijcmas.2017.612.497 